\title{
ARTICLES
}

\section{SUFISM AND SUZUKI SHŌSAN'S JAPANESE ZEN TEACHINGS}

\author{
Yasushi Suzuki*
}

\begin{abstract}
This paper aims to compare the ways toward true enlightenment taught by Islam's Sufi tradition and the Japanese Zen teacher, Suzuki Shōsan. Despite differences in fundamental motivation and ultimate goal, the paper will identify a degree of compatibility between both traditions, particularly in terms of their emphasis on: (1) becoming moral and conveying ethical ideals, (2) devoting oneself to one's daily work in the proper spirit, and (3) making services for society in order to overcome the obstacles which human beings frequently encounter. Although the peaceful and non-violent Sufi intellectual tradition has been denigrated by recent militant jihad movements and radical Islamism, this paper aims to shed an analytical light on the universal values and ethics Sufism shares with an Eastern religious teaching in order to contribute towards the promotion of an atmosphere of moderation in society.
\end{abstract}

Keywords: Buddhism, Jihad, Nio-Zen, Sufism, Suzuki Shōsan, Zen Philosophy.

\section{Introduction}

Jihad-ism is more of a political phenomenon than a religious one. The widespread hostility some Muslims feel towards Western aggression and domination has sometimes led even religiously indifferent but politically irritated Muslims to sympathise with jihadists - and even though Muslim scholars have unambiguously opposed jihad-ism's penchant for intentionally killing non-combatants (Kamali, 2013). Moreover, and as pointed out by Mohammad Hashim Kamali, the root causes of many present-day conflicts have very little to do with religion, even if they may appear to have some religious implications. ${ }^{1}$ Despite this, however, our globalising society, which includes Muslims and non-Muslims alike, is forced to face an intensifying threat from Islamic exclusivism, including the misuse of jihad and takfir (the excommunication of other Muslims) by violent extremists. How should we respond to this threat? 
Sufism - or Islam's mystical tradition - is a powerful non-violent competitor to Islamic fundamentalism. Sufi ideology, which is the inner or esoteric dimension of Islam, and while beginning with the Shari'ah as the basis of religious life, seeks to take a step further, towards the inner Truth (Haqiqah) of religion (Nasr, 2007). The ultimate aim of Sufism is an elaboration of the teachings of the Qur'an and of the Prophet through the 'greater' jihad, or the daily fight each individual experiences against his or her temptations. According to Sufism, 'battles' are to be conducted at all levels, not only against the ego-personality, but also against (and for instance) material life, economic crises, poverty, new diseases and so on.

This Sufi 'ethos', as Max Weber termed it (see Weber, 2002), is, in my view, compatibility with the Japanese Zen teachings of Suzuki Shōsan (1579-1655). In the early Edo period, Shōsan taught that true enlightenment comes during one's daily tasks: "Whether one is tilling fields, or selling wares, or even confronting an enemy in the heat of battle, direct enlightenment will occur at key moment's of one's day to day life" (Suzuki S., 2015: 45). Some scholars, including the prominent Japanese philosopher of comparative religion, Hajime Nakamura (1912-1999), and the well-known Japanese writer, Shichihei Yamamoto (19211991), insist that the characteristic Japanese ethos of endeavouring to work (i.e. of respecting the virtue of diligence and industriousness) is attributable to the penetration of the teachings of Suzuki Shōsan throughout Japanese society (Nakamura, 1996; Yamamoto, 1997; 2006). ${ }^{2}$

The Prophet of Islam said, "Whoever knows his self, knows his Lord," meaning that self-knowledge leads to knowledge of the Divine. Sufism takes this saying (hadith) very seriously and endeavours to put it into practice (Nasr, 2007). In fact, and as we discuss later, several scholars point out that Sufism's emphasis on this potential for personal contact with the Divine through self-knowledge creates a universality with other ideologies and religions (Nakamura, 1971; 1989; 2007; Nicholson, 1996). This paper aims to introduce the Zen teachings of Suzuki Shōsan as a means of furthering discussions on this potential universality of Islamic mysticism.

The sanctity and dignity of human life, which together constitute the most cherished values of human civilisation, are rooted in spirituality and ethics not war: "Senseless wars, border clashes, military occupation, the arms race and suicide bombings have not only failed to resolve any conflict, they have added to the size of the challenge" (Kamali, 2013: 183). Although the wisdom of both Sufism and Eastern philosophy may not immediately stop violent extremists, I believe that wisdom is nonetheless worthy of attention because, in the long run, it can contribute to the denial of various levels of exclusivism.

This paper will begin by looking directly at the universality of Sufism. This first section will also introduce the interpretation of the 'greater' jihad offered 
by Cheikh Khaled Bentounes, an important Sufi Shaykh. After this first section, the paper will look at Shōsan's history and the essence of his teachings, before moving on to compare, contrast and analyse the peaceful and non-violent aspects of both traditions. Finally, the paper will conclude with the hope that it can contribute towards an atmosphere of moderation in society.

\section{Sufi Perspectives and Their Universality}

It is reported that during the early formation of Islam, after the Muslims returned from a huge battle with the enemy, the Prophet of Islam, peace and blessing be upon him, said: "You have returned from a smaller jihad (battle), and now it is incumbent upon you to perform your greater jihad." When the astonished people asked him what could be greater than the jihad they had just returned from, the Prophet, peace and blessings be upon him, said: "The battle with ones nafs (egopersonality)" (Bonnin, n.a.; Bentounes, 2007: 48-9). This hadith emphasises two fundamentally important issues. First, it points to the difficult task of our internal jihad. Second, it establishes the necessity of the battle we must wage against our nafs (our ego-personality). The Prophet is letting us know that victory in the outer jihad is not enough for mankind to live in peace and harmony. Rather, it only provides the necessary space to do our most important work, which is the jihad against our nafs (Bonnin, n.a.; Napoleoni, 2014). The Sufi tradition in particular pays close attention to an elaboration of the Qur'anic and Prophetic teachings on this 'greater' jihad, the daily fight each individual wages against his or her temptations.

Quite often, one finds that historically-orientated scholarly writings describe Sufism as the mystical aspect of Islam. This kind of description suggests that Sufism involves a personal contact with the Divine brought about through an exploration of the inner meaning of Islamic religious practice. Nicholson (2002) points out that Muhammad, who had something of the mystic in him, felt God as both far and near, transcendent and immanent. In the latter regard, he saw Allah as the light of the heavens and the earth, as a Being who works in the world and in the soul of man:

"If My servants ask thee about Me, lo, I am near" (Q 2: 186); "We (God) are nearer to him than his own neck-vein" (Q 50: 16); "And in the earth are signs to those of real faith, and in yourselves, What! do ye not see?" (Q 51: 20-21).

Nevertheless, Ernst (1997) points out that as a term, 'mysticism' is subject to debate and confusion, leading some scholars to reject it altogether as a suitable descriptive term for Sufism. In contrast, non-academic sources, including 
some published by Sufis themselves, describe Sufism as the universal spirit of mysticism - that is, as the spirit at the heart of all religions (Ernst, 1997: xvii). We should pay more attention to this universality of Sufism.

Nicholson (2002) points out that Sufism cannot be traced back to a single definite origin. He illustrates, for example, how the tradition's ascetic and quietistic tendencies are in harmony with Christian theology. Indeed, many of the oldest Sufi biographies cite Gospel texts and the apocryphal sayings of Jesus. Moreover, the Christian anchorite (rahib) often appears in Sufi texts as a teacher capable of giving instruction and advice to wandering Muslim ascetics. But in addition to these influences, Nicholson also points out the conspicuous place of gnosis in early Sufi speculation, suggesting contact with Christian Gnosticism. He refers, for instance, to the following version of the doctrine of the seventy thousand veils which, and as explained by a modern Rifa' $i$ dervish, shows clear traces of Gnosticism:

Seventy Thousand Veils separate Allah, the One Reality, from the world of matter and of sense. And every soul passes before his birth through these seventy thousand. The inner half of these are veils of light: the outer half, veils of darkness. For every one of the veils of light passes through, in this journey towards birth, the soul puts off a divine quality: and for every one of the dark veils, it puts on an earthly quality. Thus the child is born weeping, for the soul knows its separation from Allah, the One Reality, And when the child cries in its sleep, it is because the soul remembers something of what it has lost. Otherwise, the passage through the veils has brought with it forgetfulness (nisyan): and for this reason man is called insan. He is now, as it were, in prison in his body, separated by these thick curtains from Allah.

But the whole purpose of Sufism, the Way of the dervish, is to give him an escape from this prison, and apocalypse of the Seventy Thousand Veils, a recovery of the original unity with The One, while still in this body. The body is not to be put off; it is to be refined and made spiritual - a help and not a hindrance to the spirit. It is like a metal that has to be refined by fire and transmuted. And the sheikh tells the aspirant that he has the secret of this transmutation. We shall throw you into the fire of Spiritual Passion', he says, 'and you will emerge refined.' (Nicholson, 1996: 29-30).

Nicholson (1996; 2002) further points out how, before the Mohammedan conquest of India in the eleventh century, the teachings of Buddha exerted considerable influence in Eastern Persia and Transoxania. He concludes that 
Sufism, so far as it is an ethical self- culture, ascetic meditation, and intellectual abstraction, owes a good deal to the Buddhist influences which earlier permeated these regions. By contrast, the Sufi conception of the passing-away (fana) of the individual self into the Universal Being is certainly of Indian origin.

What can we draw from the wisdom of Sufism today? While Orientalists have been interested in Sufism as a descriptive term for a body of religious beliefs and practices, Muslim mystics have traditionally used it in a prescriptive way, to convey certain ethical and spiritual ideals (Ernst, 1997: xvi-xvii). Today, it is to these ideals that we should pay particular attention to: Tonaga (2013) refers to the 'tripolar' structure of Sufism (see figure 1), combining mysticism (represented by the $x$-axis), ethics and morality ( $y$-axis), and folk religious beliefs (z-axis). In particular, the $y$-axis (ethics) represents the core virtues embodied in the values of Islam and could, potentially, resurrect Islam in the modern period. Indeed, in Central Asian countries, there has been a resurgence of Islamic practice directed by Sufism and its ethical values. Since the $y$-axis (ethics) is so important for the resurrection of Islam, we may say that there is no substantial difference between the phrases "to become a good Muslim" and "to become a good Sufi".

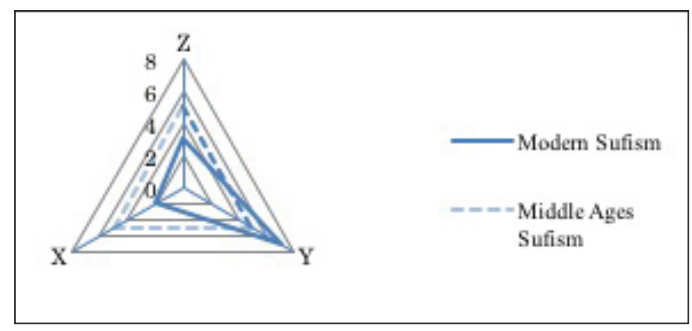

Figure 1: Illustration of the tripolar structure of Sufism, created upon Tonaga (2013: 47)

As mentioned earlier, this paper is concerned with an elaboration of the Qur'anic and Prophetic teachings on the 'greater' jihad, or the daily fight each individual wages against his or her temptations. According to Bentounes (2007), who is a leading Sufi Shaykh, the 'greater' jihad is the jihad for souls and can be traced back to the very origin of humanity. After we, as human beings, were given intellect and knowledge by God, we came to know our ignorance as well as our responsibility to the universe surrounding us. At the same time, we realized that we should have the ability to choose our own destiny, to choose between good and evil. According to Bentounes, this is the background to making jihad important and meaningful in our daily lives (Bentounes, 2007: 48-9). According to him, 'battles' are to be conducted on every level, not just against the ego- personality, but also against (and for instance) material life, economic crises, poverty, new 
diseases and so on. The concept of (the greater) jihad should really play out in our daily lives, not just in physical battles with weapons: "We should not be satisfied only with the battle against ego-personality. As a witness of knowing the Truth, we should make contributions and services to human beings. The contributions should be made in each professional field; if you are an educator, medical doctor, politician, you have to endeavour to work using your full capacity and knowledge. Your enlightenment would come in making services. All the professional works have the element of making services" (Bentounes, 2007: 50).

This Sufi-based insight into the greater jihad is, in my view, compatible with the Zen teachings of Suzuki Shōsan. Let us therefore now look to this figure. ${ }^{3}$

\section{The Essence of the Teachings of Suzuki Shōsan}

Suzuki Shōsan (鈴木正三) was a Japanese samurai who served under the Shogun Tokugawa Ieyasu, the unifier of Japan whose clan, the Tokugawas, would rule the country for the next 250 years (the Edo period). Born into a warrior family in the province of Mikawa (present-day Aichi Prefecture) in 1579, Shōsan was raised during one of Japanese history's bloodiest periods. In 1621, however, and after participating in several battles, including the Battle of Sekigahara and the Battle of Osaka, he renounced life as a warrior and became a Zen Buddhist monk. Shōsan subsequently travelled throughout Japan, seeking out Zen masters and training in several hermitages and temples, most notably at Myōshin-ji in Kyoto, where he was a student of Gudō Toshoku (1577-1661). In 1642, Shōsan, along with his brother, built 32 Buddhist temples throughout Japan. He then went on to write several treatises before his death in 1655, age 76 .

Suzuki Shōsan developed his own style of Zen, called Niō Zen, or Guardian King Zen. In Buddhism, the Niō are two guardian deities who stand on either side of a temple gateway. Each carries a thunderbolt-like weapon (kongosho) that, according to esoteric Buddhist teachings, symbolises the diamondhard wisdom of the enlightened mind. Suzuki Shōsan, former warrior turned monk, seized upon the vital energy symbolized by these two ferocious-looking deities; he emphasized the importance of this energy to his students, while also demonstrating the need to cultivate it in all activities (Braverman, 1994: 3). Sometimes, he even asked learners to physically emulate the postures of the $\mathrm{Niō}$ (as well as other warrior deities, like Fudo and Bishamonten) in order to aid them in their concentration.

Several aspects of Shōsan's teachings stand out as particularly relevant to the modern world: his insistence that Buddhism be meaningful to people in all walks of life; his assertion that it can be practiced during one's daily tasks; his use of 'death awareness' as a means of arousing vital energy; and his injunction 
that all religious practice, whether zazen, nembutsu, or mantra, be performed with the valorous spirit of the Niō (Braverman, 1994: 14; see also Suzuki D., 2000: 313-4).

To each of the four social classes in feudal Japan, Shōsan demonstrated that, if their daily work was performed in the proper spirit, they were doing Buddha's work. To farmers, he said: "Farming is itself a Buddhist activity. There is no need to seek practice elsewhere. Your body is the Buddha-body, your mind the Buddha-mind, and your work the work of the Buddha. ... If you cultivate the land, reciting Namu Amida Butsu with every movement of the hoe, you will surely reach Buddhahood. Just leave everything to Providence, be honest, and do not arouse personal desires..." (Braverman, 1994: 14-15). The value of their work, Shōsan told farmers, was demonstrated by the fact that heaven had entrusted them with the responsibility of nourishing the world. When they persevered in their work, painfully hard as it might be, their minds were consequently clear and unvexed - meaning that, in essence, they were doing Buddha's work.

To artisans, Shōsan taught that all trades are in line with Buddhist practices, that Buddhahood can therefore be attained through sincere work as craftsmen. Shōsan claimed that, although everyone possesses Buddha-nature, people unaware of that fact may stray from the Buddhist path and become deluded ordinary beings. To prevent this, people needed do nothing other than perform their trade with a firm faith in their own Buddha- nature.

Concerning merchants, a group who were traditionally regarded with suspicion in feudal Japan as the occupants of the lowest rung of the social ladder, and even when the need for their services (and hence their actual importance) grew rapidly, Shōsan formulated a Buddhist ethic that gave them the spiritual guidance needed for their profession. Shōsan did not discourage merchants from making a profit; in fact, he tells them that, as a reward from heaven, their profits will be high if they trade without greed or clinging. But, he adds, if they despise wealth, great faith will arise within them, with enlightenment emerging through a constant and unshakable meditation derived from that faith.

In essence, Shōsan sought to demonstrate that the distinction between the sacred recluse and the worldly commoner was artificial. This led him to declare that Buddhist teachings and the teachings of the World were one: "The World Dharma is the same of the Buddha Dharma. If you do not have faith that you can attain enlightenment through the World Dharma, you know nothing of the true essence of Buddhism..." (see Braverman, 1994: 16). Shōsan's dedication to bringing Buddhism to people from all segments of society intensified as he grew older. He believed that the virtue of Buddhism depended on its usefulness to one's country and to the people around you (Braverman, 1994). 


\section{Analysis}

The ground-breaking study by Nakamura (1971), entitled "Structural Analysis of Dhikr and Nembutsu," examined some of the similarities between Sufism and Buddhism - namely, how each tradition denies the value of this transient world, instead choosing to reject it as worthless. According to Nakamura, both traditions require humans to reorient their lives by shifting their ultimate concern from this world to the Hereafter - that is, to the meeting with God in Paradise for Sufism and to a rebirth in the Pure Land for Buddhism. Moreover, both traditions have similar means for achieving this: Sufism practices $d h i k r$ (or the repeated utterance of the Creator's name) while some forms of Buddhism (such as Honen Buddhism) favour nembutsu (the repeated utterance of Amida Buddha's name). ${ }^{4}$

In this paper, however, we are specifically interested in the similarity between Sufi practices and the teachings of Suzuki Shōsan. In essence, and as the above overview demonstrates, both insist that true enlightenment comes from performing one's daily tasks. This is illustrated by table 1, which summarises the fundamental motivations and ways to enlightenment described by Sufism (in particular, Cheikh Khaled Bentounes' perspective of it) and Niō-Zen.

\begin{tabular}{|l|l|l|}
\hline & Sufism & $\begin{array}{l}\text { Nio-Zen (Shōsan's) } \\
\text { philosophy }\end{array}$ \\
\hline $\begin{array}{l}\text { Fundamental } \\
\text { motivation }\end{array}$ & $\begin{array}{l}\text { Seeking a personal relationship with } \\
\text { the Divine. }\end{array}$ & $\begin{array}{l}\text { Seeking salvation from } \\
\text { suffering and difficulty. }\end{array}$ \\
\hline Eays towards & $\begin{array}{l}\text { - Become moral through knowing and } \\
\text { loving the Divine. } \\
\text { - Convey ethical ideals } \\
\text { - Perform work with full capacity and } \\
\text { knowledge. } \\
\text { - Battle (greater jihad) against ego- } \\
\text { personality, as well as against the } \\
\text { various obstacles human beings } \\
\text { frequently encounter. }\end{array}$ & $\begin{array}{l}\text { awareness' as a means of } \\
\text { arousing vital energy. } \\
\text { - Devote oneself to } \\
\text { one's daily work with a } \\
\text { proper and sincere spirit, } \\
\text { abandoning personal } \\
\text { desires. } \\
\text { - Nourish the world. }\end{array}$ \\
\hline Goals & $\begin{array}{l}\text { True enlightenment: the Sufi } \\
\text { conception of the 'passing-away' } \\
\text { (fana) of the individual self into the } \\
\text { Universal Being. }\end{array}$ & $\begin{array}{l}\text { True enlightenment: } \\
\text { transcend the sufferings of } \\
\text { the 'wheel of life'. }\end{array}$ \\
\hline
\end{tabular}

Table 1: Comparison between Sufi and Nio-Zen teachings on the way toward enlightenment, as taught mainly to lay followers. 
From this table, it becomes clear that differences exist between the traditions as to fundamental motivations and ultimate goals. For instance, the motivation to seek enlightenment in Sufism is rather 'extraverted', characterised by a wish to know and love the Absolute Existence. Niō-Zen, however, is rather more 'introverted' by comparison, seeking to develop self-control in the face of daily sufferings and difficulties. Likewise, the goals sought in each tradition appear to be different, too. For Sufis, the ultimate objective is personal contact with the Divine through the 'passing-away' of the individual self into the Universal Being. By contrast, for Buddhists the ultimate objective is to transcend the sufferings stemming from the wheel of life (a cycle of rebirth). ${ }^{6}$

But in spite of these differences, we do find some similarities concerning the ways towards enlightenment taught (mainly to lay followers) by both traditions. In particular, we see compatibility in: (1) becoming moral and conveying ethical ideals; (2) devoting oneself to one's daily work in the proper spirit; and (3) making services to help society overcome the obstacles human beings frequently encounter.

Suzuki Shōsan taught his lay followers, "Whether one is tilling fields, or selling wares, or even confronting an enemy in the heat of battle, direct enlightenment will occur at key moment's of one's day to day life" (see Suzuki, S. 2015). In the context of Buddhism, Shōsan therefore saw true enlightenment in an untraditional way; he discarded the belief that enlightenment can only occur in seclusion, when renouncing the world, and instead argued that true Buddhism has nothing to do with "gentle piety or theory, even though most monks were taught to practice in this manner" (Suzuki S. 2015). Shōsan's untraditional way of seeking true enlightenment made him something of an 'extremist' within orthodox Buddhism. But nevertheless, his teachings were widely embraced by his lay followers. As mentioned earlier, some scholars even insist that the characteristic Japanese ethos of endeavouring to work is attributable to the penetration of Shōsan's teachings throughout Japanese society (Nakamura, 1996; Yamamoto, 1997; 2006). In particular, Yamamoto (2006) points out that Shōsan's Niō-zen teachings influenced a subsequent moral education movement called Shin-gaku ('Heart Learning'). This originated during the Edo period with Ishida Baigan (1685-1744) and sought to popularise ethics among the common people.

Nevertheless, Shōsan's view is certainly compatible with Sufism's perspective of the greater jihad: by utilising the interpretation of this term offered by Bentounes (presented above), we observe that the jihad for souls is traceable to the origins of humanity and is nothing more or less than being aware of both humanity's ignorance and its responsibility to the universe around it. According to Bentounes, therefore, Sufis are required to make contributions and services to humanity in order to know Truth. They are encouraged to endeavour to work 
using their full capacity and knowledge, because only by doing so will they attain true enlightenment.

In addition, it is worth noting that in both traditions lay followers are encouraged to practice these teachings in their daily lives. In the context of Niō-zen, this point is fully discussed above, while for Sufism it is manifested in the tariqa (school or order) system, with the murshid (Sufi guide) at its heart. According to Nakamura (1989), Sufism as an 'individual' practice reserved for a limited number of elites evolved during the twelfth and thirteenth centuries into this tariqa system, where Muslim 'lay-followers' were organised by a murshid and able to implement the latter's teachings in their daily lives.

In sum, for the Sufi 'battles' are made against the ego-personality. Sufism therefore constitutes a peaceful and non-violent aspect of Islam - one which is clearly compatible with Suzuki Shōsan's teachings about the path to true enlightenment. As Nicholson (1996; 2002) points out, however, the Buddhist moralises himself while the Sufi becomes moral only through knowing and loving God. However, in the famous 'Ten Ox-herding Pictures', a series of drawings that, accompanied by prose and verse, depict the Zen path to enlightenment, the ox has been interpreted as representing the human mind, in the sense of the original 'Mind', or humanity's original nature. The pictures and words therefore attempt to represent the levels of understanding this original Mind passes through on its route to enlightenment. The ox herder, on the other hand, represents the practitioner of Buddhism as he tries to grasp his original nature. Over the course of the pictures, the ox and the ox herd, originally two separate entities, gradually merge (Braverman, 1994: 83). This merging reminds us of the Sufi concept of fana. Moreover, the final picture, entitled 'Entering the Marketplace with Giving Hands', depicts a selfless person offering outstretched hands to the people. This picture affirms Shōsan's conviction that Zen must come to the people - or, in his words, "The World Dharma and the Buddha Dharma are one" (Braverman, 1994: 83). Both of the traditions therefore suggest the importance of abandoning ego-personality and making services for society.

\section{Concluding Comments: Promote an Atmosphere of Moderation in Society}

On 28 April 2016, the S. Rajarathnam School of International Studies (RSIS), Singapore, conducted a conference entitled 'Islam in the Contemporary World'. This conference aimed to examine and address the current challenges facing Muslim societies worldwide, in order to evaluate the future of Islam as a creative, open and vibrant civilisation capable of co-existing confidently with modernity and plurality (RSIS Conference on "Islam in the Contemporary 
World", Executive Summary, Event Report, 28 April 2016). Ahmad Fauzi Abdul Hamid, one of the panellists invited to the Conference, pointed out that, as radical Islamists violate Islam's peaceful tendencies, there is a need for Muslims to more actively observe moderation, as reflected by the Qur'anic description of them as Ummatan Wasatan (the moderate community) (Hamid, 2016). According to Hamid, this concept not only refers to the moderate community, but also to the just community. Therefore, the presence of $a d l$ (justice) in practice is central to the Muslim ability to regain the centre ground. However, Hamid points out that the concept of justice is frequently manipulated by those Islamists groups who claim to fight for Islam.

During our discussion, we observed the universality of the ethos and ethics of Sufism, particularly with regards to Shōsan's teachings. But, it appears that Sufism's peaceful and non-violent intellectual tradition has been denigrated, especially by recent militant jihadi movements and radical Islamism. This again highlights the importance of Hamid's emphasis on 'being moderate', or of striking a balance between th e liberal and the conservative. He also proposes that Muslim intellectuals play an integral role in disowning those scholars who promulgate rigid interpretations of Islam. In particular, he argues that the concept of takfir requires rethinking, if not outright rejection, in order to promote an atmosphere of moderation. As a traditional source of authority in Islam, Sufism could constitute a strong rival to Islamic fundamentalism (Tonaga, 2013: 264). I believe that studies of the universal values and ethics present within Sufism (and other religious philosophies) could help create an atmosphere of moderation in society.

Ali Unsal, another panellist invited to the above-mentioned conference, pointed out that historically speaking the Islamic intellectual tradition has been willing to interact with secular trends. For example, as Islamic civilisation expanded geographically and culturally, it encountered other civilisations, including the Greeks, Byzantines, Persians and so on. As it did so, Muslim scholars learnt from those other cultures (Unsal, 2016). Unsal is concerned, however, that this tradition of engagement has been undermined. If Islam is to progress, he argued that it must resurrect this spirit as part of a 'second renaissance', where intellectuals can "be open-minded; combine Islamic sciences, modern sciences, and the spiritual life; have love for truth; have love of research and knowledge; be brave and serious when they represent what they believe; believe in tolerance and dialogue with others; be responsible intellectuals; have understanding of civilisational perspectives; be aware of mindsets in [the] modern and postmodern age; have consciousness of problems in the world; revivify tradition by developing various methods for knowledge; consider originality and quality in their work; give importance to institutionalisation of research; accept differences 
in methods of intellectual and research methods while avoiding dissociation; and lastly be involved in dialogue with and synthesis of different perspectives from other intellectual traditions" (Unsal, 2016).

The wisdom of Sufism and Eastern philosophy combined may not immediately stop violent extremists. However, I believe their wisdom is still to be sought because in the long term it can contribute towards the denial of various levels of exclusivism. This may also contribute to the 'second renaissance' of Islamic intellectualism.

\section{Acknowledgement}

I would like to thank Professor Dr. Mohammad Hashim Kamali, Founding CEO of the International Institute of Advanced Islamic Studies (IAIS) Malaysia, for his invaluable and insightful comments on an earlier version of this paper. Also, I would like to thank Dr. Mohammed Azam Mohamed Adil, Siti Mar'iyah Chu Abdullah, Alinda Aziz, and all the other researchers and members of staff at IAIS Malaysia. Their contributions were in various ways invaluable.

\section{Notes}

* Yasushi Suzuki, PhD (Economics), LLM (International Economic Law) is a Professor at Ritsumeikan Asia Pacific University, Japan. He was engaged as a visiting fellow at the International Institute of Advanced Islamic Studies (IAIS) Malaysia in the Fall of 2016. He has an undergraduate degree from Waseda University, Tokyo, and a doctorate from the University of London. His main research interests are the institutional political economy of financial and economic development, and the philosophy of economics. He can be reached at: szkya@apu.ac.jp.

1. Kamali (2013) raises several examples: the Israeli-Palestinian conflict is about land, dispossession and the right to self-determination; the conflict in Kashmir is also about the right to self-determination; the Mindanao conflict in the Phillippines is about land, historical rights, unemployment and poverty; the Maluku conflict (in Indonesia) arose from socio-political and economic circumstances, not religious ones (Kamali, 2013: 183).

2. There are very few studies concerning the origins of the Japanese spirit of diligence and industriousness. Of those which do exist, however, arguably the most important is by Yasuo Yuasa (1925-2005), a Japanese philosopher who pioneered the comparison of Western and Japanese business ethics. He first identified the moral education movement known as Shin-gaku (see the main body of the text) as the key factor in the development of the Japanese spirit of hardwork. This founder of this movement, Ishida Baigan, was the son of a farmer and began studying ethical doctrines when apprenticed to a merchant house. 
His later teachings were based on this experience as a merchant; he argued that the content of honesty derives from complying with contract agreements and respecting mutual property rights (Yuasa, 1967: 52).

3. Arthur Braverman has produced a prominent translation of Shōsan's work (Braverman, 1994). During the following section, I utilise his translation to describe Shōsan's teachings, but while also referring to the original text.

4. T. Suzuki Daisetz (1870-1966), the well-known Japanese Zen philosopher who helped spread interest in Zen Buddhism to the West, was also interested in the apparent similarity between dhikr and nembutsu (see Suzuki D., 2000).

5. According to Braverman (1994), Shōsan was not simply concerned with overcoming a fear of death. Rather, it was from a consciousness of that fear that his practices evolved. For him, the awareness of death constituted real living; he felt that the promise of enlightenment kept many practitioners from living in the here and now (Braverman, 1994: 17).

6. In Buddhism, rebirth (or reincarnation) refers to a belief that the actions of a person during his lifetime will lead to a new existence after death, in an endless cycle. According to the teachings of Buddhism, this cycle is unsatisfactory and painful; it only stops when liberation is achieved by extinguishing desire.

\section{References}

Bentounes, C. K. (2007) Le Soufisme, Coeur de L'Islam, the Japanese edition (Sufism, Islam no kokoro), translated by Nakamura, K., Iwanami Shoten, Tokyo (written in Japanese).

Bonnin, F. F. N. (n.a.) Peace and the Inner Jihad, Australian Centre for Sufism and Irfanic Studies, available at: http:/www.australiansuficentre.org/sufi_teachings peacejihad.htm (accessed 4 March 2016).

Braverman, A. (1994) Warrior of Zen: The Diamond-hard Wisdom Mind of Suzuki Shōsan, Kodansha International

Ernst, C. (1997) The Shambhala Guide to Sufism, Boston: Shambhala.

Kamali, M. H. (2013) Peace as a Universal Islamic Value, Islam and Civilisational Renewal. 4(2), 169-187.

Hamid, A. F. A. (2016) Religion, Politics and Violence in the Muslim World, RSIS Conference on "Islam in the Contemporary World", Event Report 28 April 2016.

Nakamura, K. (1971) Structural Analysis of Dhikr and Nembutsu, Orient, 7, 75-96.

Nakamura, K. (1989) Islam Shisou 1, Iwanami (in Japanese).

Nakamura, K. (2007) Translator's comments on Bentounes, Cheikh Khaled (2007), Le Soufisme, Coeur de L'Islam, the Japanese edition (Sufism, Islam no kokoro), Iwanami Shoten, Tokyo (in Japanese)

Nakamura, H. (1998) Kinsei Nihon no Hihan teki Seishin, Nihon no Shiso III, Shunshu-sha (in Japanese). 
Napoleoni, L. (2014) The Islamist Phoenix: The Islamic State and the Redrawing of the Middle East, Seven Stories Press, New York.

Nasr, S. H. (2008) The Garden of Truth: The Vision and Promise of Sufism, Islam's Mystical Tradition, Harpercollins, New York.

Nicholson, R. A. (1996) The Mystics of Islam (Islam no Shimpi Shugi), translated by Nakamura, K., Heibon-sha (in Japanese).

Nicholson, R. A. (2002) The Mystics of Islam, revised version, World Wisdom Books; Revised. Unsal, A. (2016) Religion, Politics and Violence in the Muslim World, RSIS Conference on "Islam in the Contemporary World", Event Report 28 April 2016.

Suzuki, D. (2000) Japanese spirituality (Nihon teki reisei), Kadokawa Sofia Bunko (in Japanese).

Suzuki, S. (2015) Suzuki Shōsan Chosaku-Shu I/II, edited by Kato Michiko, ChuoKoron sha (in Japanese).

Tonaga, Y. (2013) Islam to Sufism, Nagoya University Press (in Japanese).

Weber, M. (2002) The Protestant Ethic and the Spirits of Capitalism: New Introduction and Translation by Stephen Kalberg. Oxford: Blackwell.

Yamamoto, S. (1997) Rongo no yomikata. Bungei Shunjyuu.

Yamamoto, S. (2006) Nihon Shihon Shugi no Seishin, Business-sha (in Japanese).

Yuasa, Y. (1967) Keizai-jin no moraru (Morale of economic man). Tokyo: Hanawashinsho. 